\title{
DAYA ADAPTASI TIGA SPESIES IKAN PATIN PADA LINGKUNGAN YANG BERBEDA
}

\author{
Evi Tahapari*\#, Jadmiko Darmawan*), Raden Roro Sri Pudji Sinarni Dewi* ${ }^{*}$ \\ *) Balai Riset Pemuliaan Ikan \\ *) Pusat Riset Perikanan
}

(Naskah diterima: 24 November 2017; Revisi final: 28 Desember 2017; Disetujui publikasi: 28 Desember 2017)

\begin{abstract}
ABSTRAK
Penampilan fenotipe suatu organisme ditentukan oleh faktor genotipe dan faktor lingkungan tempat organisme tersebut hidup. Penelitian ini bertujuan untuk mempelajari daya adaptasi tiga spesies ikan patin yang dipelihara di lokasi berbeda. Ikan patin siam, patin jambal, dan patin pasupati dengan rataan bobot $20 \mathrm{~g}$ dipelihara di tiga lokasi yang berbeda, yaitu: kolam air tenang, tambak, dan keramba jaring apung. Pemeliharaan ikan dilakukan selama empat bulan. Selama pemeliharaan, ikan diberi pakan berupa pelet komersial dengan kadar protein 30\% 32\% Jumlah pakan yang diberikan pada bulan kesatu sampai keempat secara berturut-turut adalah sebanyak $5 \%$ 4\% dan 3\%dari biomassa ikan per hari. Pakan diberikan dengan frekuensi tiga kali sehari. Hasil penelitian menunjukkan adanya interaksi yang signifikan antara genotipe ikan patin dengan lingkungan ekosistem yang berbeda dan daya adaptasi yang spesifik dari ketiga spesies ikan patin. Ketiga spesies ikan patin memiliki pertumbuhan sama bila dipelihara di kolam air tenang. Ikan patin jambal tumbuh dengan baik $(\mathrm{P}<0,05)$ jika dipelihara di keramba jaring apung $(\mathrm{KJA})$ dan tambak,

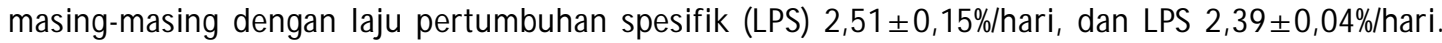
Pertumbuhan ikan patin siam dan pasupati adalah sama pada ketiga lokasi penelitian $(P>0,05)$. Ketiga spesies ikan patin mempunyai daya adaptasi lingkungan yang sempit sehingga budidayanya akan optimal jika dilakukan di lokasi tertentu saja.
\end{abstract}

KATA KUNCl: ikan patin; genotipe; lingkungan; fenotipe

ABSTRACT: Adaptability of three species of pangasiid in different environment. By: Evi Tahapari, Jadmiko Darmawan, and Raden Roro Sri Pudji Sinarni Dewi

\begin{abstract}
The phenotypic appearance of an organism is determined by genotypes and environmental factors in which the organism lives. This study aims to study the adaptability of three species of pangasiids reared in three different environments. Three species of catfish (Siamese pangasiid, jambal pangasiid, and pasupati) with an average weight of 20 gwere kept in stagnant water pond, brackishwater pond, and floating net cage). Fishes were reared for four months. During the rearing, fish were fed by commercial pellets with 30\%32\%protein content. The amount of feed given in the first month to the fourth month was $5 \% 4 \%$ and $3 \%$ of the biomass per day. Feed was given three times a day. The results showed the significant interaction between pangasiid genotype and environment, and specific adaptability on three species of pangasiid. Jambal pangasiid grew better in floating net cage (SGR 2.51 $0.15 \%$ day). Pasupati pangasiid grew better in stagnant water pond (SGR $2.05 \pm 0.03 \%$ day). Siamese pangasiid grew better in stagnant water pond (SGR 2.02 $\pm 0.05 \%$ day) and brackishwater pond (SGR 2.31 $\pm 0.09 \%$ day). The three species of catfish have a narrow environmental adaptability so that the cultured will be optimal if done in a particular location.
\end{abstract}

\section{KEYWORDS: pangasius; genotype; environment; phenotype}

\section{PENDAHULUAN}

Ikan patin merupakan salah satu komoditas prioritas air tawar yang dibudidayakan di Indonesia. Ikan patin termasuk ke dalam famili Pangasiidae, merupakan salah satu jenis ikan konsumsi air tawar

\footnotetext{
\# Korespondensi: Balai Riset Pemuliaan Ikan. Jl. Raya Sukamandi No. 2, Subang, Jawa Barat 41256.

Tel. + 62260520500

E-mail: evitahapari@yahoo.co.id
}

yang bernilai ekonomis tinggi. Ikan patin banyak diminati oleh masyarakat, terutama di Sumatera dan Kalimantan. Dari 25 jenis ikan patin yang ada, 14 jenis di antaranya terdapat di Indonesia (Gustiano et al., 2003). Beberapa jenis ikan patin sebagai ikan budidaya sudah banyak dikenal di masyarakat, di antaranya adalah ikan patin siam, patin jambal, dan patin pasupati. Ikan patin siam memiliki karakter fekunditas yang tinggi dan dagingnya berwarna merah. Ikan patin jambal 
memiliki karakter warna daging yang putih sehingga memenuhi standar kualitas ekspor, namun fekunditasnya rendah. Ikan patin pasupati merupakan ikan patin hasil hibridisasi antara ikan patin siam betina dengan ikan patin jambal jantan, yang memiliki karakter warna daging putih serta dapat diproduksi dalam jumlah besar seperti halnya ikan patin siam (LRPTBPAT, 2006).

Budidaya ikan patin dilakukan pada kondisi lingkungan yang sangat beragam seperti ketinggian yang berbeda, kualitas air yang berbeda, dan sistem manajemen budidaya yang berbeda. Kemampuan adaptasi ikan patin siam, ikan patin jambal, dan ikan patin pasupati pada lingkungan yang berbeda selama ini belum diketahui sehingga perlu dilakukan kajian untuk mengevaluasi adanya interaksi antara faktor lingkungan dan genotipe ikan patin. Pemahaman tentang interaksi genotipe dengan lingkungan diperlukan untuk membantu proses identifikasi genotipe unggul. Cara yang umum digunakan untuk mengenali genotipe ideal adalah dengan menguji seperangkat genotipe atau varietas harapan pada beberapa lingkungan. Berdasarkan pada hasil analisis variannya akan diketahui ada tidaknya interaksi genotipe dengan lingkungan (GxE). Interaksi GxE dapat digunakan untuk mengukur stabilitas suatu genotipe (Lin \& Binns, 1988) karena stabilitas fenotipe pada suatu kisaran lingkungan tergantung dari besarnya interaksi GxE. Jika tidak terjadi interaksi GxE, maka penentuan genotipe ideal akan sangat mudah dilakukan, yaitu dengan memilih genotipe-genotipe harapan dengan rata-rata hasil yang lebih tinggi. Namun apabila terjadi interaksi GxE, genotipe akan diuji di berbagai lokasi untuk mengukur kemampuan daya hasilnya yang berbeda pada setiap lokasi pengujian. Hal ini berarti juga hasil tertinggi suatu genotipe pada suatu lingkungan tertentu belum tentu memberikan hasil tertinggi pula pada lingkungan yang berbeda. Hal yang demikian akan menyulitkan dalam pemilihan genotipe ideal yang beradaptasi dan stabil pada semua lingkungan (Perkins \& Jinks, 1968).

Penampilan yang diperlihatkan oleh suatu individu disebut fenotipe yang merupakan hasil ekspresi dari penampilan genotipe individu pada suatu lingkungan tertentu dan interaksinya (Falconer, 1989). Besarnya pengaruh lingkungan terhadap pertumbuhan individu dan adanya tanggapan dari tiap genotipe terhadap perubahan lingkungan memerlukan kajian khusus mengenai interaksi genotipe $x$ lingkungan. Kajian interaksi genotipe $x$ lingkungan telah banyak dipaparkan, antara lain oleh Yan et al. (2000). Macam interaksi tersebut penting diketahui karena dapat menghambat kemajuan seleksi dan mengganggu pemilihan strain unggul dalam pengujian di lapangan (Eberhart-Russell, 1966) dan seringkali menyulitkan pengambilan kesimpulan secara akurat dalam perco baan varietas/genotipe dalam kisaran lingkungan yang luas (Nasrullah, 1981).

Penelitian ini bertujuan untuk mempelajari interaksi antara faktor genotipe dengan lingkungan, dan daya adaptasi tiga spesies ikan patin yang dipelihara di tiga lokasi berbeda. Kegiatan penelitian meliputi kegiatan pembesaran yang dilakukan di kolam air tenang, keramba jaring apung dan tambak bersalinitas rendah.

\section{BAHAN DAN METODE}

\section{Ikan Uji}

Spesies ikan uji yang digunakan dalam penelitian ini adalah ikan patin siam (Pangasianodon hypophthalmus), ikan patin jambal (Pangasius djambal), dan ikan patin pasupati yang merupakan hasil persilangan antara ikan patin siam betina dengan ikan patin jambal jantan. Ikan diperoleh dari Balai Riset Pemuliaan Ikan di Sukamandi. Ukuran ikan yang digunakan sekitar 20 gram.

\section{Lokasi Percobaan}

Evaluasi pertumbuhan ketiga spesies ikan patin dilakukan di tiga kondisi yang berbeda, yaitu kolam air tenang (air tawar), tambak bersalinitas (3,9-7 $\mathrm{g} / \mathrm{L})$, dan keramba jaring apung. Kolam air tenang (dilengkapi saluran pemasukan air dengan debit 0,20,5 L/detik) yang digunakan berlokasi di Balai Riset Pemuliaan Ikan Sukamandi, Jawa Barat. Tambak bersalinitas yang digunakan berlokasi di Kecamatan Belanakan Kabupaten Subang, Jawa Barat dan Lokasi keramba jaring apung berada di Waduk Darma Kuningan, Jawa Barat. Kondisi lingkungan pada ketiga lokasi tersebut disajikan pada Tabel 1.

\section{Pemberian Pakan}

Selama pemeliharaan, ikan diberi pakan berupa pelet komersial dengan kadar protein 30\% 32\% Jumlah pakan yang diberikan pada bulan kesatu sampai keempat adalah sebanyak 5\% 3\% dari biomassa ikan per hari. Pakan diberikan dengan frekuensi tiga kali sehari.

\section{Parameter}

Parameter yang diamati selama penelitian berlangsung adalah: pertumbuhan, konversi pakan, dan sintasan. Laju pertumbuhan spesifik, konversi pakan, dan sintasan dihitung dengan menggunakan rumus: 
Tabel 1. Kondisi pemeliharaan tiga spesies ikan patin di lingkungan yang berbeda

Table 1. Rearing condition of three pangasiid species on different environment

\begin{tabular}{|c|c|c|c|}
\hline \multirow[b]{2}{*}{ Parameter (Parameter) } & \multicolumn{3}{|c|}{ Lokasi penelitian (Research location) } \\
\hline & $\begin{array}{l}\text { Kolam air tenang } \\
\text { Stag nant water }\end{array}$ & $\begin{array}{c}\text { Tambak } \\
\text { brackishwater }\end{array}$ & $\begin{array}{l}\text { Keramba jaring apung } \\
\text { Floating cage }\end{array}$ \\
\hline Padat tebar (ekor $\left./ \mathrm{m}^{3}\right) /$ Density (ind $\left./ \mathrm{m}^{3}\right)$ & 10 & 10 & 25 \\
\hline Lama pemeliharaan (bulan) / Rearing period (month) & 4 & 4 & 4 \\
\hline Ukuran kolam atau jaring $\left(\mathrm{m}^{3}\right) /$ Pond size $\left(\mathrm{m}^{3}\right)$ & 50 & 6 & 6 \\
\hline Salinitas (g/L) / Salinity (g/L) & 0 & $3.9-7$ & 0 \\
\hline Ketinggian (mdpl)/ Elevation (mdpl) & 26 & 1 & 717 \\
\hline $\mathrm{pH}$ & $7.0-9.0$ & $7.5-8.7$ & $7.5-8.0$ \\
\hline Oksigen terlarut (mg/L) / Dissolved oxygen (mg/L) & $0.2-9.1$ & $2.1-11.8$ & $3.6-8.0$ \\
\hline
\end{tabular}

Laju pertumbuhan spesifik (Castell \& Tiews, 1980)

$$
\begin{aligned}
& a=\frac{\ln \text { bobot akhir }(g)-\ln \text { bobot awal }(g)}{\text { Waktu pemeliharaan }} \times 100 \% \\
& a=\text { Laju pertumbuhan spesifik (\%hari) }
\end{aligned}
$$

Konversi pakan (NRC, 1977)

$$
\begin{aligned}
& \mathrm{KP}=\frac{\text { Jumlah pakan (bobot kering) yang diberikan }(\mathrm{g})}{(\mathrm{Wt}+\mathrm{D})-\text { Wo }} \\
& \mathrm{KP}=\text { Konversi pakan } \\
& \mathrm{Wt}=\text { Bobot total ikan pada akhir penelitian }(\mathrm{g}) \\
& \mathrm{Wo}=\text { Bobot total ikan pada awal penelitian }(\mathrm{g}) \\
& \mathrm{D}=\text { Bobot total ikan yang mati selama penelitian }(\mathrm{g})
\end{aligned}
$$

Sintasan (SR)

$$
\mathrm{SR}=\frac{\text { Jumlah ikan pada akhir penelitian (ekor) }}{\text { Jumlah awal benih yang dipelihara (ekor) }} \times 100
$$

\section{Analisis Data}

Data yang diperoleh dalam penelitian ini ditampilkan dalam bentuk grafik dan tabel. Untuk mengetahui pengaruh lingkungan, jenis ikan patin, dan ada/tidaknya interaksi antara lingkungan dan spesies yang berbeda terhadap pertumbuhan, konversi pakan (FCR), dan sintasan maka dilakukan analisis variansi (ANOVA) berdasarkan Uji-F. Analisis variansi dilakukan dengan menggunakan program SPSS versi 19. Jika terdapat perbedaan yang signifikan antar perlakuan pada taraf selang kepercayaan $95 \%$ maka dilakukan uji lanjut menggunakan uji beda nyata terkecil (LSD, least significant differences) untuk menilai adanya perbedaan signifikan antar kelompok.

\section{HASIL DAN BAHASAN}

\section{Pertumbuhan}

Fenotipe pada ikan tergantung kepada genotipe, lingkungan, dan interaksi antara genotipe dan lingkungan. Respons spesifik terhadap lingkungan yang beragam mengakibatkan adanya interaksi antara genotipe dan lingkungan $(G x L)$, pengaruh interaksi yang besar secara langsung akan mengurangi kontribusi dari genetik dalam penampilan akhir (Gomez \& Gomez, 1985). Uji daya adaptasi dari tiga spesies ikan patin pada beberapa lokasi perlu dilakukan untuk mengetahui sifat-sifat unggul dari setiap spesies. Berdasarkan Tabel 2, nilai signifikansi lingkungan, spesies, dan interaksi lingkungan $x$ spesies menunjukkan angka 0,000 atau $<$ 0,05 (alfa) yang berarti bahwa semua variabel independen (lingkungan, spesies, dan interaksi lingkungan $x$ spesies) berpengaruh secara signifikan terhadap laju pertumbuhan spesifik. Nilai $R^{2}$ menunjukkan nilai determinasi berganda semua variabel independen dengan dependen. Nilai di atas 0,897 (mendekati 1), berarti bahwa ada korelasi yang kuat antara faktor lingkungan, spesies, dan interaksi lingkungan $x$ spesies terhadap laju pertumbuhan spesifik. Berdasarkan nilai $F$, bahwa faktor spesies (genotipe) paling dominan dalam menentukan pertumbuhan.

Laju pertumbuhan spesifik tiga spesies ikan patin yang dipelihara di lingkungan yang berbeda menunjukkan perbedaan yang signifikan (Tabel 3; $P<0,05)$. Pada pemeliharaan di kolam air tenang, ketiga spesies ikan patin menunjukkan laju pertumbuhan yang sama. Pada pemeliharaan di tambak, ikan patin jambal tumbuh lebih baik dibandingkan dengan pasupati, namun tidak berbeda dengan ikan patin siam. Pada pemeliharaan di keramba 
Tabel2. Analisis variansi pengaruh lingkungan, spesies, dan interaksi lingkungan $\mathrm{x}$ spesies terhadap laju pertumbuhan spesifik ikan patin

Table 2. Analysis of the variance of environment, species, and environment $x$ species interaction impact on specific growth rate of pangasiid

\begin{tabular}{lccccc}
\hline \multicolumn{1}{c}{ Sumber (Source) } & $\begin{array}{c}\text { Jumlah kuadrat } \\
\text { Sum of squares }\end{array}$ & $\begin{array}{c}\text { df } \\
\text { df }\end{array}$ & $\begin{array}{c}\text { Rataan kuadrat } \\
\text { Mean square }\end{array}$ & $\begin{array}{c}\text { F } \\
\text { F }\end{array}$ & $\begin{array}{c}\text { Sig. } \\
\text { Sig. }\end{array}$ \\
\hline Lingkungan (Environment) & 0.348 & 2 & 0.174 & 19.499 & 0 \\
Spesies (Species) & 0.463 & 2 & 0.231 & 25.946 & 0 \\
Interaksi lingkungan x spesies & 0.59 & 4 & 0.148 & 16.541 & 0 \\
Interaction environment x species & 0.161 & 18 & 0.09 & & \\
Galat (Error) & $\mathbf{1 . 5 6 2}$ & $\mathbf{2 6}$ & & & \\
\hline \multicolumn{1}{c}{ Total (Total) } & &
\end{tabular}

a. $R^{2}=0.897$

a. $\quad$ R squared $=0.897$ (adjusted $R$ squared $=0.851$ )

jaring apung, ikan patin jambal menunjukkan pertumbuhan terbaik dibandingkan ikan patin siam dan patin pasupati (Tabel 3; $\mathrm{P}<0,05)$.

Pertumbuhan ikan patin siam, patin jambal, dan patin pasupati dipengaruhi oleh faktor genotipe, lingkungan dan interaksi antara faktor genotipe dan lingkungan. Hasil penelitian ini serupa dengan penelitian Sae-Lim et al. (2013) pada ikan rainbow trout, yang menunjukkan terdapatnya interaksi yang kuat antara genotipe dan lingkungan dalam memengaruhi pertumbuhan ikan rainbow trout. Demikian juga dilaporkan Ariyanto \& Listiyowati (2015) bahwa varietas ikan nila (GMT, merah NIFI, NIRWANA, dan BEST) yang diuji di lokasi berbeda mempunyai penampilan fenotipe yang dipengaruhi oleh faktor internal (genetik), faktor eksternal (lingkungan), serta interaksi yang nyata antara kedua faktor tersebut. Hasil penelitian Luan et al. (2008) pada ikan nila menunjukkan adanya interaksi yang kuat antara genotipe dan lingkungan dalam memengaruhi bobot panen dan sintasan. Hasil penelitian serupa dilaporkan Listiyowati et al. (2008); Ariyanto \& Muslikhin (2011);
Ariyanto et al. (2011); Robisalmi et al. (2011) bahwa lokasi budidaya yang berbeda pada pemeliharaan ikan nila menghasilkan tingkat produktivitas yang berbeda pula. Perbedaan produksi diduga karena adanya perbedaan kondisi geografis, agro-klimatologis, dan teknologi budidaya yang dikembangkan antar lokasi. Perbedaan tersebut berakibat pada respons genotipe ikan yang tidak sama sehingga menghasilkan penampilan fenotipe yang bervariasi. Lingkungan ekosistem yang berbeda pada pemeliharaan ikan patin mengakibatkan keragaman pertumbuhan. Genotipe yang memberikan hasil tertinggi pada suatu lokasi tidak sama dengan lokasi lain. Berdasarkan hasil pengujian, ketiga jenis ikan patin menunjukkan pertumbuhan yang spesifik jika dipelihara di lingkungan yang berbeda. Ikan patin jambal tumbuh dengan baik jika dipelihara di keramba jaring apung dan tambak. Ikan patin pasupati tumbuh dengan baik jika dipelihara di kolam air tenang. Ikan patin siam tumbuh dengan baik jika dipelihara di kolam air tenang dan tambak. Tingginya laju pertumbuhan ikan patin jambal yang dipelihara di kerambajaring apung diduga

Tabel 3. Laju pertumbuhan spesifik (\%hari) tiga spesies ikan patin pada lingkungan yang berbeda selama 4 bulan pemeliharaan

Table 3. Specific growth rate (\%day) of three species of pangasiid on different environment condition during 4 months of rearing

\begin{tabular}{lccc}
\hline \multirow{2}{*}{ Lingkungan (Environment) } & \multicolumn{2}{c}{ Spesies ikan patin (Species of pangasiid) } \\
\cline { 2 - 4 } & Siam & Jambal & Pasupati \\
\hline Kolam air tenang (Stagnant water pond) & $2.02 \pm 0.05^{\mathrm{a}}$ & $1.98 \pm 0.09^{\mathrm{a}}$ & $2.05 \pm 0.03^{\mathrm{a}}$ \\
Tambak (Brackiswater pond) & $2.31 \pm 0.09^{\mathrm{ab}}$ & $2.39 \pm 0.04^{\mathrm{a}}$ & $2.15 \pm 0.12^{\mathrm{b}}$ \\
Keramba jaring apung (Floating net cage) & $1.97 \pm 0.08^{\mathrm{b}}$ & $2.51 \pm 0.15^{\mathrm{a}}$ & $1.74 \pm 0.12^{\mathrm{b}}$ \\
\hline
\end{tabular}

Nilai yang diikuti huruf superskrip yang sama pada lajur yang sama tidak berbeda nyata $(P>0,05)$

The value followed by the same superscript letters in the same line did not significantly different $(P>0.05)$ 
karena kondisi lingkungan budidaya di KJA yang relatif sama dengan kondisi habitat asli ikan patin jambal di alam yaitu di sungai-sungai besar yang memiliki arus yang relatif kuat dan kedalaman yang stabil sehingga berakibat pada kadar oksigen terlarut dalam kisaran optimal (3,6-8 mg/L) dan fluktuasi suhu air yang relatif kecil. Menurut Slembrouck et al. (2005), habitat Pangasius jambal hidup di sungai-sungai besar di Pulau Jawa, Sumatera, dan Kalimantan yang secara umum kondisi perairannya memiliki arus yang kuat dan kedalaman yang stabil. Demikian juga dilaporkan bahwa pemeliharaan di keramba, benih ikan atau induk patin jambal memperlihatkan tingkat pertumbuhan yang lebih tinggi daripada ikan patin siam. Organisme dengan kualitas genetik yang baik akan menghasilkan penampilan fenotipe yang optimal jika didukung oleh lingkungan yang sesuai dengan kebutuhan organisme tersebut. Namun demikian, organisme dengan kualitas genetik yang rendah tidak akan menghasilkan penampilan fenotipe optimal meskipun kualitas lingkungannya diperbaiki (Tave, 1996; Noor, 2000).

Pemilihan spesies ikan patin yang tepat untuk dikembangkan pada lokasi yang spesifik akan memengaruhi produktivitas. Pemahaman interaksi genotipe $x$ lingkungan sangat diperlukan untuk mengidentifikasi genotipe yang hasilnya tinggi pada lingkungan spesifik atau stabil pada lingkungan yang luas. Pemilihan genotipe untuk lingkungan spesifik didasarkan pada nilai duga interaksi suatu genotipe $x$ lingkungan yang nyata menggambarkan kemampuan suatu genotipe mengekspresikan sebagian besar gengen yang menguntungkan pada lingkungan tertentu sehingga memberikan hasil yang tinggi. Dengan demikian, interaksi genotipe $x$ lingkungan menentukan ekspresi gen terhadap keragaan suatu karakter (Sujiprihati et al., 2006; Abdulai et al., 2007). Demikian juga jika dicermati pada ketiga spesies ikan patin yang dipelihara di tambak cenderung memiliki nilai laju pertumbuhan yang relatif tinggi (Tabel 3), hal ini menunjukkan bahwa lingkungan budidaya yang bersalinitas memberikan efek yang positif terhadap peningkatan laju pertumbuhan ikan. Setiawati dan Suprayudi (2003) dari hasil penelitiannya melaporkan bahwa ikan nila merah yang dipelihara pada media bersalinitas menunjukkan adanya perbedaan Iaju pertumbuhan spesifik yang lebih baik $(P<0,05)$. Terjadinya pertumbuhan yang lebih baik tersebut diduga karena tekanan osmotik media pemeliharaan mendekati tekanan osmotik tubuh ikan nila merah, atau disebut isoosmotik, sehingga pemanfaatan sumber energi pakan menjadi lebih efektif. Penelitian serupa dilaporkan Sutrisno (2008) bahwa ikan sidat yang dipelihara dalam air dengan salinitas $5 \mathrm{ppt}$ memiliki laju pertumbuhan spesifik yang paling tinggi dibandingkan dengan salinitas lainnya. Pada tingkat salinitas 5 ppt diduga tekanan osmotik lingkungan mendekati tekanan osmotik dalam tubuh ikan sidat sehingga konsentrasi ion relatif seimbang. Ikan yang dipelihara pada salinitas yang mendekati konsentrasi ion dalam darah, maka energi lebih banyak digunakan untuk pertumbuhan dan lebih sedikit untuk proses osmoregulasi. Pada kondisi salinitas optimal penggunaan energi untuk osmoregulasi relatif lebih kecil dibandingkan dengan salinitas diluar optimal, dan pada salinitas optimal tersebut laju pertumbuhan mencapai maksimal (Stickney, 1979). Dengan demikian dari ketiga jenis ikan patin yang dipelihara di tambak dengan salinitas 3,9-7 ppt diduga tekanan osmotik media pemeliharaan mendekati tekanan osmotik tubuh ikan uji, atau disebut isoosmotik sehingga memiliki nilai laju pertumbuhan spesifik yang relatif tinggi akibat dari pemanfaatan sumber energi pakan yang lebih efektif. Dengan demikian, pemeliharaan ikan patin di tambak menghasilkan nilai FCR yang relatif lebih rendah dibandingkan dengan pemeliharaan di KAT maupun di KJA.

\section{Konversi Pakan}

Berdasarkan Tabel 4, nilai signifikansi lingkungan dan interaksi lingkungan $x$ spesies menunjukkan angka $<0,05$ (alfa) yang berarti bahwa lingkungan dan interaksi antar lingkungan x spesies berpengaruh secara signifikan terhadap tingkat konversi pakan. Adapun spesies yang berbeda tidak berpengaruh secara signifikan terhadap konversi pakan. Berdasarkan nilai $F$, faktor lingkungan paling dominan dalam menentukan konversi pakan.

Konversi pakan merupakan gambaran tingkat efisiensi ikan dalam memanfaatkan energi yang diperoleh dari makanan yang dikonsumsi. Konversi pakan yang rendah mengindikasikan bahwa penggunaan energi oleh ikan untuk aktivitas hidup dan yang hilang melalui jalur ekskresi (feses dan urin) relatif kecil sehingga ikan mempunyai kelebihan energi cukup besar yang dapat digunakan untuk pertumbuhan, demikian pula sebaliknya. Nilai rasio konversi pakan dapat dipengaruhi oleh beberapa faktor di antaranya adalah: kandungan nutrisi dan jumlah pakan yang diberikan serta lingkungan budidaya.

Konversi pakan pada ikan patin siam yang dipelihara padalingkungan yang berbeda menunjukkan perbedaan yang signifikan, demikian juga pada ikan patin jambal dan ikan patin pasupati, konversi pakan dipengaruhi oleh lingkungan $(P<0,05)$. Konversi pakan pada ikan patin jambal lebih rendah apabila dipelihara di tambak atau keramba jaring apung dibandingkan di kolam air tenang. Konversi pakan ikan patin pasupati yang dipelihara di tambak relatif lebih rendah dibandingkan jika dipelihara di keramba jaring apung (Tabel 5). 
Tabel 4. Analisis variansi pengaruh lingkungan, spesies, dan interaksi lingkungan x spesies terhadap konversi pakan pada ikan patin

Table 4. Analysis of the variance of environment, species, and environment $x$ species interaction impact on feed conversion ratio of pangasiid

\begin{tabular}{lccccc}
\hline \multicolumn{1}{c}{ Sumber (Source) } & $\begin{array}{c}\text { Jumlah kuadrat } \\
\text { Sum of squares }\end{array}$ & $\begin{array}{c}\text { df } \\
\text { df }\end{array}$ & $\begin{array}{c}\text { Rataan kuadrat } \\
\text { Mean square }\end{array}$ & $\begin{array}{c}\mathbf{F} \\
\mathbf{F}\end{array}$ & $\begin{array}{c}\text { Sig. } \\
\text { Sig. }\end{array}$ \\
\hline Lingkungan (Environment) & 0.618 & 2 & 0.309 & 6.403 & .008 \\
Spesies (Species) & 0.205 & 2 & 0.102 & 2.123 & .149 \\
Interaksi lingkungan x spesies & 0.626 & 4 & 0.156 & 3.243 & .036 \\
Interaction environment x species & & & & \\
Galat (Error) & 0.869 & 18 & 0.048 & & \\
\hline Total koreksi (Corrected total) & 2.317 & 26 & & & \\
\hline a. R ${ }^{2}=0.625$ & & & & & \\
a. R squared= $=0.625$ (adjusted R squared $=0.459)$ &
\end{tabular}

Semakin rendah nilai FCR berarti semakin efisien ikan memanfaatkan pakan untuk pertumbuhan. Ketiga jenis ikan patin yang dipelihara di KAT dan KJA memiliki nilai konversi pakan yang signifikan $(P<0,05)$. Ikan patin pasupati yang dipelihara di KAT memiliki konversi pakan yang terendah $(\mathrm{P}<0,05)$ dibandingkan dengan ikan patin siam dan jambal pada lokasi pemeliharaan yang sama. Namun demikian perbedaan nilai konversi pakan relatif tidak berpengaruh terhadap laju pertumbuhan spesifik. Nilai konversi pakan terendah dari ketiga jenis ikan patin yang dipelihara di KJA dimiliki pada ikan patin jambal dan memberikan laju pertumbuhan spesifik tertinggi dibandingkan dengan ikan patin siam dan pasupati. Sedangkan ketiga jenis ikan patin yang dipelihara di kolam tambak tidak memiliki nilai konversi pakan yang signifikan (Tabel 5; $P>0,05)$, namun demikian berpengaruh terhadap laju pertumbuhan spesifik.

Penelitian serupa dilaporkan Tahapari (2013) bahwa nilai rasio konversi pakan pada pembesaran ikan patin Siam dan Pasupati yang dipelihara di kolam air tawar dan di tambak salinitas rendah (< 10 ppt) selama 4-6 bulan menunjukkan bahwa nilai rasio konversi pakan di tambak relatif lebih rendah daripada yang dipelihara di kolam air tawar, yaitu 1,24-1,27 dan 1,36-1,41. Ikan yang dipelihara pada salinitas yang mendekati konsentrasi ion dalam darah, energi lebih banyak digunakan untuk pertumbuhan dan lebih sedikit untuk proses metabolisme. Pemeliharaan ikan pada kondisi yang isoosmotik mempunyai efek yang menguntungkan, karena adanya penyimpanan energi yang disebabkan menurunnya energi untuk proses osmosis dan efek ionik, dengan demikian pertumbuhan akan meningkat. Rendahnya nilai konversi pakan pada pemeliharaan di tambak diduga akibat adanya pengaruh salinitas air pemeliharaan dan pemanfaatan pakan alami air kolam untuk kebutuhan tumbuh ikan. Ikan patin termasuk dalam golongan pemakan segala (omnivora) hal ini terbukti dari hasil analisis food habit ikan patin yang dipelihara di tambak memiliki nilai preponderence index: 70,29\%phytoplankton + zooplankton; 7,83\%saresah tumbuhan; $15,65 \%$ pellet dan 6,26\%detritus; sedangkan yang dipelihara di kolam air tawar; 14,63\% phytoplankton + zoo-

Tabel 5. Konversi pakan tiga spesies ikan patin pada lingkungan yang berbeda selama 4 bulan pemeliharaan

Table 5. Feed conversion ratio of three species of pangasiid in different environments during 4 months of rearing

\begin{tabular}{lccc}
\hline \multirow{2}{*}{ Lingkungan (Environment) } & \multicolumn{3}{c}{ Spesies ikan patin (Species of pangasiid) } \\
\cline { 2 - 4 } & Siam & Jambal & Pasupati \\
\hline Kolam air tenang (Stagnant water pond) & $1.91 \pm 0.26^{\mathrm{a}}$ & $1.87 \pm 0.28^{\mathrm{a}}$ & $1.68 \pm 0.09^{\mathrm{b}}$ \\
Tambak (Brackiswater pond) & $1.35 \pm 0.11^{\mathrm{b}}$ & $1.42 \pm 0.15^{\mathrm{b}}$ & $1.61 \pm 0.12^{\mathrm{b}}$ \\
Keramba jaring apung (Floating net cage) & $1.86 \pm 0.42^{\mathrm{a}}$ & $1.33 \pm 0.06^{\mathrm{b}}$ & $1.93 \pm 0.23^{\mathrm{a}}$ \\
\hline
\end{tabular}

Nilai yang diikuti huruf superskrip yang sama pada kolom yang sama tidak berbeda nyata $(P>0,05)$

The value followed by the same superscript in the same coloumn did not significantly different $(P>0.05)$ 
plankton; 5,9\% saresah tumbuhan; 50,10\% moluska; $5,96 \%$ pelet dan 23,19\% detritus (Tahapari, 2013). Informasi ini memberikan gambaran bahwa pakan alami memberikan kontribusi yang relatif efektif dalam mendukung pertumbuhan ikan patin dan dapat menekan nilai konversi pakan(Tahapari, 2013).

\section{Sintasan}

Berdasarkan Tabel 6, nilai signifikansi lingkungan, spesies, dan interaksi lingkungan $x$ spesies menunjukkan angka > 0,05 (alfa) yang berarti bahwa lingkungan, spesies, dan interaksi lingkungan $x$ spesies tidak berpengaruh secara signifikan terhadap sintasan.

Berdasarkan Tabel 7, sintasan selama penelitian berkisar antara 78,67-98,33\% Hasil analisis sidik ragam menunjukkan pengaruh yang tidak nyata antar spesies terhadap lingkungan yang berbeda $(P>0,05)$. Hasil yang diperoleh pada penelitian ini tidak jauh berbeda dengan yang dilaporkan Tahapari et al. (2016) bahwa sintasan pada pemeliharaan ikan patin Siam dan Pasupati di tambak dengan salinitas 1-8 ppt berkisar antara 90,6797,67\% Tingkat sintasan ikan selama pemeliharaan tergolong baik. Menurut Fatimah (1992) dalam Murjani (2011), bahwa sintasan ikan sangat bergantung pada daya adaptasi ikan terhadap makanan dan lingkungan, status kesehatan ikan, padat tebar, dan kualitas air yang cukup untuk mendukung pertumbuhan.

\section{KESIMPULAN}

Pertumbuhan ikan patin siam, patin jambal, dan patin pasupati secara signifikan dipengaruhi oleh faktor genotipe, lingkungan, dan interaksi antara genotipe dan lingkungan. Ikan patin jambal tumbuh dengan baik jika dipelihara di keramba jaring apung (KJA) dengan laju pertumbuhan spesifik (LPS) $2,51 \pm 0,15 \%$ Ikan patin pasupati tumbuh dengan baik jika dipelihara di kolam air tenang (KAT) dengan LPS $2,05 \pm 0,03 \%$ Ikan patin siam tumbuh dengan baik jika dipelihara di kolam air tenang dan tambak dengan LPS 2,02 $\pm 0,05 \%$ dan 2,31 $\pm 0,09 \%$ Tingkat konversi pakan sangat dipengaruhi oleh faktor lingkungan. Konversi

Tabel 6. Analisis variansi pengaruh lingkungan, spesies, dan interaksi lingkungan $\mathrm{x}$ spesies terhadap terhadap sintasan

Table 6. Analysis of the variance of environment, species, and environment $x$ species interaction impact on survival rate

\begin{tabular}{|c|c|c|c|c|c|}
\hline Sumber (Source) & $\begin{array}{l}\text { Jumlah kuadrat } \\
\text { Sum of squares }\end{array}$ & $\begin{array}{l}\text { df } \\
\text { df }\end{array}$ & $\begin{array}{l}\text { Rataan kuadrat } \\
\text { Mean square } \\
\end{array}$ & $\begin{array}{l}\mathbf{F} \\
\mathbf{F}\end{array}$ & $\begin{array}{l}\text { Sig. } \\
\text { Sig. }\end{array}$ \\
\hline Lingkungan (Environment) & 483.055 & 2 & 241.527 & 3.495 & .052 \\
\hline Spesies (Species) & 202.032 & 2 & 101.016 & 1.462 & .258 \\
\hline $\begin{array}{l}\text { Interaksi lingkungan x spesies } \\
\text { Interaction environment x species }\end{array}$ & 296.147 & 4 & 74.037 & 1.071 & .399 \\
\hline Galat (Error) & 1.243 .837 & 18 & 69.102 & & \\
\hline Total koreksi (Corrected total) & 2.225 .071 & 26 & & & \\
\hline
\end{tabular}

Tabel 7. Sintasan ( $\%$ tiga spesies ikan patin pada lingkungan yang berbeda selama 4 bulan pemeliharaan

Table 7. Survival rate (\%) of three species of pangasiid in different environment during 4 months of rearing

\begin{tabular}{lccc}
\hline \multirow{2}{*}{ Lingkungan (Environment) } & \multicolumn{3}{c}{ Spesies ikan patin (Species of pangasiid) } \\
\cline { 2 - 4 } & Siam & Jambal & Pasupati \\
\hline Kolam air tenang (Stagnant water pond) & $88.13 \pm 5.28^{\mathrm{a}}$ & $78.67 \pm 2.86^{\mathrm{a}}$ & $92.73 \pm 4.47^{\mathrm{a}}$ \\
Tambak (Brackishwater pond) & $92.78 \pm 0.96^{\mathrm{a}}$ & $98.33 \pm 0.00^{\mathrm{a}}$ & $96.67 \pm 2.89^{\mathrm{a}}$ \\
Keramba jaring apung (Floating net cage) & $91.11 \pm 9.37^{\mathrm{a}}$ & $82.00 \pm 21.57^{\mathrm{a}}$ & $89.33 \pm 1.76^{\mathrm{a}}$ \\
\hline
\end{tabular}

Nilai yang diikuti huruf superskrip yang sama pada kolom yang sama tidak berbeda nyata $(P>0,05)$

The value followed by the same superscript in the same coloumn did not significantly different $(P>0.05)$ 
pakan pada ikan patin jambal lebih rendah apabila dipelihara di tambak $(1,42 \pm 0,15)$ atau keramba jaring apung $(1,33 \pm 0,06)$. Konversi pakan ikan patin pasupati yang dipelihara di tambak $(1,61 \pm 0,12)$ atau kolam air tenang $(1,68 \pm 0,09)$ relatif lebih rendah. Pada ikan patin siam, konversi pakan di tambak lebih rendah $(1,35 \pm 0,11)$ jika dibandingkan dipelihara di KJA dan KAT. Sintasan pada tiga spesies ikan patin tidak dipengaruhi oleh lingkungan, spesies, dan interaksi lingkungan $x$ spesies. Ketiga spesies ikan patin mempunyai daya adaptasi lingkungan yang sempit sehingga budidayanya akan optimal jika dilakukan di lokasi tertentu saja.

\section{UCAPAN TERIMA KASIH}

Penulis menyampaikan rasa terima kasih dan penghargaan yang setulus-tulusnya kepada para teknisi komoditas patin Balai Riset Pemuliaan Ikan, Sukamandi dan pihak-pihak yang terlibat selama koleksi data maupun dalam penyelesaian makalah ini.

\section{DAFTAR ACUAN}

Abdulai, M.S., Sallah, P.Y.K., \& Safo-Kantanka, 0. (2007). Maize grain yield stability analysis in full season lowland maize in Ghana. Int. J. Agri. Biol., 9(1), 41-45.

Ariyanto, D., Robisalmi, A., \& Fajarwati, D. (2011). Evaluasi daya tahan larva ikan nila (Oreochromis niloticus) pada media bersalinitas (pp. 37-43). Surabaya, Prosiding Seminar Nasional Kelautan VII.

Ariyanto, D. \& Listiyowati, N. (2015). Interaksi genotipe dengan lingkungan, adaptabilitas, dan stabilitas penampilan fenotipik empat varietas unggul ikan nila (Oreochromis niloticus). Jurnal Riset Akuakultur, 10(1), 1-9.

Ariyanto, D.\& Muslikhin. (2011). Performance of red tilapia in three different levels of salinity. Ind. Aqua. J., 6(2), 123-129.

Castell, J.D. \& Tiews, K. (1980). Report of the EIFAC, IUNS and ICES Working Group on the standardization of methodology in fish nutrition research (p.24). Hamburg, Germany, ElFAC Tech.

Eberhart, S.A. \& Russel, W.A. (1966). Stability parameters for comparing varieties. Crop Sci., 6, 36-40.

Falconer, D.S. (1989). Introduction to quantitative genetics (p. 438). New York: John Willey and Sons. Inc..

Gomez, K.A. \& Gomez, A.A. (1985). Statistical procedures for agricultural research (p. 680). Canada: John Willey $\&$ Sons, Ins.

Gustiano, R., Sudarto., \& Pouyaud, L. (2003). Bagaimana Mengenali Patin Jambal. Dalam: Petunjuk Teknis Pembenihan Ikan Patin Indonesia, Pangasius djambal (p. 3-14), IRD-DKP.
Lin, C.S. \& Binns, M.R. (1988). A Method of Analysing Cultivar x Locations x Year Experiment: A New Stability Parameter. Theor. Appl. Genet. 76, 425-430.

Listiyowati, N., Ariyanto, D., \& Kusrini, E. (2008). Keragaman pertumbuhan beberapa strain tilapia pada beberapa lingkungan budidaya (pp. 63-66). Pusat Riset Perikanan Budidaya, Jakarta. Prosiding Teknologi Perikanan Budidaya.

LRPTBPAT. (2006). Dokumen usulan pelepasan patin hibrida (14 hlm). Sukamandi: Loka Riset Pemuliaan dan Teknologi Budidaya Perikanan Air Tawar.

Luan, T.D., Olesen, I., Odegard, J., Kolstad, K., \& Dan, N.C. (2008). Genotype by environment interaction for harvest body weight and survival of nile tilapia (Oreochromis niloticus) in brackiswater and freshwater ponds. International Symposium on Tilapia in Aquaculture, p. 231-240.

Murjani, A. (2011). Budidaya beberapa varietas ikan sepat rawa (Trichogaster trichopterus Pall) dengan pemberian pakan komersial. Jurnal Fish Scientiae, 1(2), 214-233.

National Research Council (NRC). (1977). Nutrient Requirement of Warmwater Fishes (p. 78). National Academic Press. Washington D.C.

Nasrullah. (1981). A modified prosedure for identifying varietal stability. Agric. Sci., 3(4), 153-159.

Noor, R.R. (2000). Genetika ternak (p. 200). Jakarta: Penebar Swadaya.

Perkins, J.M. \& Jinks, J.L. (1968). Environmental and Genotype-Environmental Component of Variability. III. Multiple Lines and Crosses. Heredity, 23, 339-356.

Robisalmi, A., Setyawan, P., \& Listiyowati, N. (2011). Keragaan pertumbuhan benih dua persilangan ikan nila (Oreochromis sp.) pada media bersalinitas ( $p$. 15-21) Surabaya, Prosiding Seminar Nasional Kelautan VII.

Sae-Lim, P., Kause, A., Mulder, H.A., Martin, K.E., Barfoot, A.J., Parsons, J.E., Davidson, J., Rexroar, C.E., van Arendonk, J.A.M., \& Komen, H. (2013). Genotype-by-environment interaction of growth traits in rainbow trout (Oncorhynchus mykiss): a continental scale study. Journal of Animal Science, 91, 5572-5581.

Slembrouck, J., Komarudin, O., Maskur., \& Legendre, M. (2005). Petunjuk Teknis Pembenihan Ikan Patin Indonesia, Pangasius djambal (p. 143). Jakarta: Kerjasama IRD dan Pusat Riset Perikanan Budidaya. Badan Riset Kelautan dan Perikanan.

Sujiprihati, S., Azrai M., \& Yuliandry, A. (2006). Keragaan genotipe jagung bermutu protein tinggi (QPM) di dua tipologi lahan yang berbeda. Agrotropika 11(2), 90-100. 
Sutrisno. (2008). Penentuan Salinitas Air dan Jenis Pakan Alami Yang Tepat dalam Pemeliharaan Benih Ikan Sidat (Anguilla Bicolor). Jurnal Akuakultur Indonesia, 7(1), 71-77.

Setiawati, M. \& Suprayudi, M.A. (2003). Pertumbuhan dan efisiensi pakan ikan nila merah (Oreochromis sp.) yang dipelihara pada media bersalinitas. Jurnal Akuakultur Indonesia, 2(1), 27-30.

Stickney, R.R. (1979). Principle of Warmwater Aquaculture (p. 375). New York: John Willey and Sons Inc.

Tahapari, E. (2013). Pembesaran Ikan Patin (Siam dan Pasupati) pada Media Pemeliharaan Berbeda (p. 15).Yogjakarta, Prosiding Seminar Nasional Tahunan
X Hasil Penelitian Kelautan dan Perikanan, Jilid I, Budidaya Perikanan.

Tahapari, E., Darmawan, J., Nurlaela, I., Pamungkas, W., \& Marnis, H. (2016). Performa ikan patin hibrida Pasupati (pangasiid) dari induk terseleksi pada sistem budidaya berbeda. Jurnal Riset Akuakultur, 11(1), 29-38.

Tave, D. (1996). Selective breeding programmes for medium sized fish farm (p. 121). FAO.

Yan, W., Hunt, L.A., Sheng, Q., \& Szlavnies, Z. (2000). Cultivar evaluation and mega-environment investigation based on GGE biplot. Crop. Sci., 40, 597-605. 